\title{
Estradiol increases cAMP in the oviductal secretory cells through a nongenomic mechanism
}

\author{
María L Oróstica ${ }^{1,2}$, John Lopez ${ }^{1,2}$, Israel Rojas ${ }^{1,2}$, Jocelyn Rocco ${ }^{1,2}$, Patricia Díaz ${ }^{1,2}$, \\ Patricia Reuquén $^{1,2}$, Hugo Cardenas ${ }^{1,2}$, Alexis Parada-Bustamante ${ }^{3}$ and Pedro A Orihuela ${ }^{1,2}$ \\ ${ }^{1}$ Laboratorio de Inmunología de la Reproducción, Facultad de Química y Biología, Universidad de Santiago de Chile, \\ Alameda 3363, Casilla 40, Correo 33, Santiago, Chile, ${ }^{2}$ Centro para el Desarrollo en Nanociencia y Nanotecnología- \\ CEDENNA, Santiago, Chile and ${ }^{3}$ Instituto de Investigaciones Materno-Infantil, Universidad de Chile, Santiago, Chile \\ Correspondence should be addressed to P A Orihuela; Email: pedro.orihuela@usach.cl
}

\begin{abstract}
In the rat oviduct, estradiol $\left(E_{2}\right)$ accelerates egg transport by a nongenomic action that requires previous conversion of $E_{2}$ to methoxyestrogens via catechol-O-methyltranferase (COMT) and activation of estrogen receptor (ER) with subsequent production of cAMP and inositol triphosphate (IP3). However, the role of the different oviductal cellular phenotypes on this $E_{2}$ nongenomic pathway remains undetermined. The aim of this study was to investigate the effect of $E_{2}$ on the levels of cAMP and IP3 in primary cultures of secretory and smooth muscle cells from rat oviducts and determine the mechanism by which $E_{2}$ increases cAMP in the secretory cells. In the secretory cells, $E_{2}$ increased cAMP but not IP3, while in the smooth muscle cells $E_{2}$ decreased cAMP and increased IP3. Suppression of protein synthesis by actinomycin $D$ did not prevent the $E_{2}$-induced cAMP increase, but this was blocked by the ER antagonist ICI 182780 and the inhibitors of COMT OR 486, G protein- $\alpha$ inhibitory $\left(G \alpha_{i}\right)$ protein pertussis toxin and adenylyl cyclase (AC) SQ 22536. Expression of the mRNA for the enzymes that metabolizes estrogens, Comt, Cyp1a1, and Cyp1b1 was found in the secretory cells, but this was not affected by $E_{2}$. Finally, confocal immunofluorescence analysis showed that $E_{2}$ induced colocalization between ESR1 (ER $\alpha$ ) and $G \alpha_{i}$ in extranuclear regions of the secretory cells. We conclude that $E_{2}$ differentially regulates cAMP and IP3 in the secretory and smooth muscle cells of the rat oviduct. In the secretory cells, $E_{2}$ increases cAMP via a nongenomic action that requires activation of COMT and ER, coupling between ESR1 and $\mathrm{G} \alpha_{\mathrm{i}}$, and stimulation of AC.
\end{abstract}

Reproduction (2014) 148 285-294

\section{Introduction}

In the female genital tract, estrogens regulate a variety of biological functions including gamete transport, oocyte fertilization, embryo development, and implantation (reviewed in Croxatto (1996)). The classical mechanism by which estradiol $\left(E_{2}\right)$ affects its target cells comprises binding to estrogen receptors (ERs) and modification of gene expression and protein synthesis (Nilsson et al. 2001). However, this model cannot explain $E_{2}$ effects that are not blocked by inhibitors of transcription or translation, or that are too rapid to be due to changes in gene expression. These features do not appear compatible with the classical genomic actions and are termed nongenomic (Lössel \& Wheling 2003, Lössel et al. 2003). Nongenomic actions of $E_{2}$ often involve activation of $\mathrm{G}$ protein- $\alpha$ inhibitory $\left(\mathrm{G} \alpha_{\mathrm{i}}\right)$, stimulation of intracellular signal transduction pathways that include generation of second messengers such as CAMP and inositol triphosphate (IP3), and activation of protein kinase A (PKA) or phospholipase $\mathrm{C}(\mathrm{PLC})$ in the $\mathrm{E}_{2}$-target cells (Nadal et al. 2001, Wyckoff et al. 2001, Acconcia et al. 2005,
Hill et al. 2010). Recently, it has been also proposed that estrogen metabolites could be responsible for some $E_{2}$ nongenomic actions (Mueck \& Seeger 2010, Rincón-Rodríguez et al. 2013).

In the rat, the duration of oviductal egg transport is dependent on ovarian hormones and mating-associated signals (for review see Croxatto (2002)). A single injection of $E_{2}$ on day 1 of the cycle or pregnancy shortens oviductal transport of eggs from the normal 72-96 to $<24$ h (Ortíz et al. 1979). We have previously demonstrated that RNA and protein synthesis inhibitors did not block $E_{2}$-induced acceleration of oviductal egg transport in unmated rats, indicating that $\mathrm{E}_{2}$ accelerates oviductal egg transport by a nongenomic mechanism (Orihuela et al. 2001). This $E_{2}$ nongenomic pathway involves a previous conversion of $\mathrm{E}_{2}$ to methoxyestradiols, mediated by the enzyme catechol-O-methyltransferase (COMT; Parada-Bustamante et al. 2007, 2010), activation of ER and adenylyl cyclase (AC) (Orihuela et al. 2003), and successive production of CAMP and IP3 (Orihuela et al. 2003, 2006, 2013). 
The rat oviduct is a tubular organ mainly composed of an intrinsic layer smooth muscle fiber, the myosalpinx, and an innermost highly folded mucosa (secretory, ciliated, and stromal cells), the endosalpinx. From the ovary to the uterus, it is possible to distinguish in the oviduct the fimbria, the ampulla, the isthmus, and the utero-tubal junction. In the ampulla, ciliated cells are more abundant whereas in the isthmus secretory cells are predominant (Croxatto 1996). Transport of oocytes through the ampulla depends mainly on the activity of ciliated cells whose cilia beat toward the uterus. In contrast, egg transport through the isthmus depends on the contractile activity of the smooth muscle cells (Moore \& Croxatto 1988a, Ríos et al. 2007). The actual vision on the mechanics involved in the acceleration of $E_{2}$-induced egg transport in the rat oviduct indicate that $\mathrm{E}_{2}$ induces the release of paracrine signals from the secretory cells initiating waves of myosalpinx (mainly composed of smooth muscle cells) contractions that lead to increase in the speed of the egg transport (Moore \& Croxatto 1988b, Croxatto 2002, Parada-Bustamante et al. 2012). Therefore in this work, we examined the contribution of the secretory and smooth muscles cells in the $\mathrm{E}_{2}$ nongenomic signaling that accelerates egg transport in the rat oviduct. First, we determined the effect of $E_{2}$ on the levels of cAMP or IP3 in the secretory and smooth muscle cells from rat oviducts. The results oriented us to investigate the mechanism by which $E_{2}$ increases CAMP in the secretory cells. Thus, we examined the effect of $E_{2}$ on the cAMP level in the secretory cells under conditions in which protein synthesis, ER, COMT, $\mathrm{G} \alpha_{\mathrm{i}}$, or AC activity was quenched by selective inhibitors. In addition, the effect of $E_{2}$ on the expression of some enzymes involved in estrogen metabolism and colocalization between ESR1 (ER $\alpha$ ) and the $\mathrm{G}_{\mathrm{i}}$ protein was determined in the oviductal secretory cells.

\section{Materials and methods}

\section{Animals}

Locally bred Sprague-Dawley rats weighing 200-260 g were used. The animals were kept under controlled temperature $\left(21-24{ }^{\circ} \mathrm{C}\right)$, and lights were on from 0700 to $2100 \mathrm{~h}$. Water and pelleted rat chows were supplied ad libitum. Female mature rats were used in the estrus stage. The phases of the estrous cycle were determined by daily vaginal smears (Turner 1961) and all females were used after showing two consecutive 4-day cycles. The care and manipulation of the animals was done in accordance with the ethical guidelines of the Universidad de Santiago de Chile.

\section{Culture of primary cells from rat oviducts}

\section{Secretory cells}

A protocol to obtain secretory cells instead of ciliated cells was performed in this work (Morales et al. 2000, 2006). For each replicate, 12 oviducts from six rats were excised and placed in pre-warmed Hanks' solution (Sigma Chemical Co.) of $\mathrm{pH}$ 7.4. The whole oviduct was cut into small $\left(4-8 \mathrm{~mm}^{2}\right)$ pieces in Hanks' solution and then the epithelial cells were mechanically removed from the rest of the tissue. The cell suspension was centrifuged at $800 \mathrm{~g}$ during $5 \mathrm{~min}$, washed, and seeded into six-well tissue culture plates coated with collagen I, rat-tail (Invitrogen) in DMEM/high modified medium with $4.0 \mathrm{mM} \mathrm{L}$-glutamine and $4.500 \mathrm{mg} / \mathrm{l}$ glucose free of Phenol Red (cat. no. SH30284.02, HyClone, Thermo Scientific, Walthman, MA, USA) supplemented with $10 \%$ (V/V) of fetal bovine serum (Cat. No. SH30396.03, HyClone), sodium pyruvate $1 \mathrm{mM}$, and antibiotics: $100 \mathrm{UI} / \mathrm{ml}$ of penicillin and $100 \mu \mathrm{g} / \mathrm{ml}$ of streptomycin. The epithelial cells were incubated at $37^{\circ} \mathrm{C}$ in an atmosphere of $5 \%$ ( $\mathrm{vol} / \mathrm{vol}$ ) $\mathrm{CO}_{2}$ for at least 3 days to $75-80 \%$ confluence and characterized by immunofluorescence staining with a cytokeratine antibody. The presence of secretory and ciliated cells in the primary cultures was determined using immunohistochemical staining for MUC1 (secretory cell marker; DeSouza et al. 1998) and $\beta$-tubulin IV (ciliated cell marker; Shao et al. 2007, Nutu et al. 2009).

\section{Smooth muscle cells}

For each replicate, 12 oviducts from six rats were excised and placed in pre-warmed Hanks' solution (Sigma Chemical Co.) of $\mathrm{pH}$ 7.4. The whole oviduct was cut into small $\left(4-8 \mathrm{~mm}^{2}\right)$ pieces in Hanks' solution and then the smooth muscle cells were mechanically removed from the rest of the tissue and treated with collagenase, type I (Invitrogen) for $1 \mathrm{~h}$ to further the disaggregation of the cells. The cell suspension was centrifuged at $1200 \mathrm{~g}$ during $5 \mathrm{~min}$, washed, and seeded into six-well tissue culture plates (Becton Dickinson \& Co., Franklin Lakes, NJ, USA) in DMEM/high modified medium with $4.0 \mathrm{mM}$ L-glutamine and $4.500 \mathrm{mg} / \mathrm{l}$ glucose free of Phenol Red (cat. no. SH30284.02, HyClone, Thermo Scientific) supplemented with 10\% (vol/vol) of fetal bovine serum (cat. no. SH30396.03, HyClone), sodium pyruvate $1 \mathrm{mM}$, and antibiotics: $100 \mathrm{UI} / \mathrm{ml}$ of penicillin and $100 \mu \mathrm{g} / \mathrm{ml}$ of streptomycin. Smooth muscle cells were incubated at $37^{\circ} \mathrm{C}$ in an atmosphere of $5 \%$ (vol/vol) $\mathrm{CO}_{2}$ for at least 7 days to reach $75-80 \%$ confluence and characterized by immunohistochemical staining with an $\alpha$-actin antibody.

\section{Treatments}

Primary cultures of secretory and smooth muscle cells were treated with $10^{-9} \mathrm{M}$ of $\mathrm{E}_{2}$ (Sigma) or ethanol $0.01 \%$ as vehicle. Other primary cultures of secretory cells were also incubated with the protein synthesis inhibitor actinomycin D (ActD, $1 \mu \mathrm{g} / \mu \mathrm{l}$, Sigma), the ER antagonist ICI $182780(25 \mu \mathrm{g} / \mu \mathrm{l}$, Tocris Bioscience, Bristol, UK), the AC inhibitor SQ $22536(7.5 \mu \mathrm{g} / \mu \mathrm{l}$, Calbiochem, La Jolla, CA, USA), the selective COMT activity inhibitor OR $486\left(25 \mu \mathrm{g} / \mu \mathrm{l}\right.$, Tocris Bioscience), or the $\mathrm{G} \alpha_{i}$ protein inhibitor pertussis toxin (PTX, $1 \mu \mathrm{g} / \mu \mathrm{l}$ ) as appropriate to each experiment. DMSO $0.01 \%$ was used as a vehicle of the inhibitors as it is more efficient than ethanol to dissolve nonpolar or semi-polar drugs.

\section{Measurement of cAMP levels}

The primary cell cultures were sonicated in $100 \mu$ of ice cold $10 \%(\mathrm{v} / \mathrm{v})$ trichloroacetic acid (TCA) and centrifuged for $15 \mathrm{~min}$ 
at $5000 \mathrm{~g}$ at $4{ }^{\circ} \mathrm{C}$. The pellet was discarded and the supernatant was washed four times with five volumes of water-saturated diethyl ether. The upper layer was discarded after each wash. Following the last wash, the aqueous extract was dried under a stream of nitrogen at $60^{\circ} \mathrm{C}$. The levels of cAMP in dried extracts were determined using Biotrak cAMP enzyme immunoassay system, cat. no. RPN 225 (Amersham Pharmacia Biotech). This kit is based on competition between unlabeled cAMP and a fixed quantity of peroxidase-labeled cAMP for a limited number of binding sites on a cAMP-specific antibody. This allows the construction of a standard curve and the measurement of cAMP levels in unknown samples. 3,3',5,5'tetramethylbenzidine/hydrogen peroxide was used as a substrate for color development. The optical density was read at $630 \mathrm{~nm}$ using a microplate reader (Bio-Tek Instruments, Inc., Winooski, VT, USA).

\section{Measurement of IP3 levels}

The primary cell cultures were sonicated in $100 \mu$ of ice-cold $1 \mathrm{M} \mathrm{TCA}$ and centrifuged for $10 \mathrm{~min}$ at $1000 \mathrm{~g}$ at $4{ }^{\circ} \mathrm{C}$. The pellet was discarded and the supernatant was incubated for $15 \mathrm{~min}$ at room temperature. TCA was removed from the supernatant with $0.5 \mathrm{ml}$ of a solution 1,1,2-trichloro-trifluoroethane (Sigma Chemical Co.)-trioctylamine (Sigma), 3:1 (v/v). The levels of IP3 were determined using the Inositol-1,4,5trisphosphate $\left[{ }^{3} \mathrm{H}\right]$ Radioreceptor Assay Kit, cat. no. NEK064 (NEN Life Science Products, Boston, MA, USA). This kit is based on a competition between non-radioactive IP3 and a fixed quantity of $\left[{ }^{3} \mathrm{H}\right]-$ IP3 for a limited number of calf cerebellum IP3 receptor-binding sites. This allows the construction of a standard curve and the measurement of IP3 levels in unknown samples.

\section{Real-time PCR}

Total RNA from primary secretory cell cultures was isolated using TRIzol Reagent (Invitrogen). One microgram of total RNA of each sample was treated with DNase I, amplification grade (Invitrogen). The single-strand cDNA was synthesized by RT using the superscript III reverse transcriptase first-strand system for RT-PCR (Invitrogen), according to the manufacturer's protocol. The Light Cycler Instrument (Roche Diagnostics $\mathrm{GmbH}$ ) was used to quantify the relative gene expression of Comt, Cyp1a1, and Cyp1b1 in the oviductal secretory cells; Gapdh was chosen as the housekeeping gene for load control. The SYBR Green I double-strand DNA binding dye (Roche Diagnostics) was the reagent of choice for these assays. Primers for Comt, 5'-CAC CTA CTG CAC ACA GAA GG-3' (sense) and 5'-GTT AGT GTG TGC ACT CGA AGC-3' (antisense); Cyp1a1, 5'-AGT TTG GGG GAG GTT ACT GGT TC-3' (sense) and 5'-GGA CAT CAC AGA CAG CCT CAT T-3' (antisense); Cyp1b1, 5'-CCT TGG GGA CTC TCA GGT TG-3' (sense) and 5'-CCA TTC TTC TGC TAC TCG TTT CG-3'; and Gapdh, 5'-ACC ACA GTC CAT GCC ATC AC-3' (sense) and 5'-TCC ACC ACC CTG TTG CTG TA-3' (anti sense). All real-time PCR assays were carried out in duplicate. The thermal cycling conditions included an initial activation step at $95{ }^{\circ} \mathrm{C}$ for $25 \mathrm{~min}$, followed by 40 cycles of denaturizing and annealing-amplification $\left(95{ }^{\circ} \mathrm{C}\right.$ for $15 \mathrm{~s}, 59{ }^{\circ} \mathrm{C}$ for $30 \mathrm{~s}$, and $72{ }^{\circ} \mathrm{C}$ for $30 \mathrm{~s}$ ), and finally one cycle of melting $\left(95-60^{\circ} \mathrm{C}\right)$. To verify specificity of the product, amplified products were subject to melting curve analysis as well as electrophoresis, and product sequencing was carried out to confirm identity using an ABI Prism310 Sequencer. The expression of Comt, Cyp1a1, and Cyp1b1 was determined using the equation: $Y=2^{-\Delta C p}$ where $Y$ is the relative expression, $C p$ (crossing point) is the cycle in the amplification reaction in which fluorescence begins to be exponential above the background base line, $-\Delta C p$ is the result of subtracting $C p$ value of Cyp1a1, Cyp1b1, and Comt from $C p$ value of Gapdh for each sample. To simplify the presentation of the data, the relative expression values were multiplied by $10^{3}$ (Livak \& Schmittgen 2001).

\section{Immunofluorescence}

Oviductal cells were fixed in cold $4 \%$ paraformaldehyde in PBS of $\mathrm{pH} 7.4-7.6$ for $2 \mathrm{~h}$, transferred to $10 \% \mathrm{w} / \mathrm{v}$ sucrose in PBS for $60 \mathrm{~min}$ at $4{ }^{\circ} \mathrm{C}$ and $30 \% \mathrm{w} / \mathrm{v}$ sucrose in PBS at $4{ }^{\circ} \mathrm{C}$ overnight. Then, they were blocked with $1 \%$ PBS-BSA for $120 \mathrm{~min}$ and incubated with mouse anti-cytokeratin (Santa Cruz Biotechnology, Inc.) or mouse anti- $\alpha$-actin (Santa Cruz Biotechnology, Inc.) antibody 1:250 and 1:500 respectively. After washing with PBS, the preparations were incubated for $2 \mathrm{~h}$ with rabbit anti-mouse IgG FITC conjugate (Santa Cruz Biotechnology, Inc.) diluted 1:1000. The sections were washed and counterstained with $1 \mu \mathrm{g} / \mathrm{ml}$ of Hoechst 33342 (Thermo Scientific, Rockford, IL, USA), washed again and then mounted in Fluoromount G. As negative controls, the primary antibody was replaced by preimmune serum. All sections were visualized under an Optiphot Epifluoresence Microscope (Olympus).

\section{Immunohistochemical}

Oviductal cells were fixed in cold $4 \%$ paraformaldehyde in

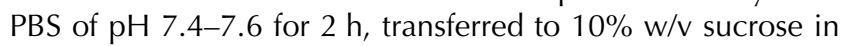
PBS for $60 \mathrm{~min}$ at $4{ }^{\circ} \mathrm{C}$ and $30 \% \mathrm{w} / \mathrm{v}$ sucrose in PBS at $4{ }^{\circ} \mathrm{C}$ overnight. Then, they were blocked with $1 \%$ PBS-BSA for $120 \mathrm{~min}$ and incubated with rabbit anti-MUC1 (Abcam, Cambridge, MA, USA) or mouse anti- $\beta$-tubulin IV (Sigma) antibody 1:100. After washing with PBS, the preparations were incubated for $2 \mathrm{~h}$ with goat anti-rabbit or anti-mouse IgG alkaline phosphatase conjugate (Chemicon International, Temecula, CA, USA). The alkaline phosphatase activity was detected by color development during incubation of the cells in $100 \mathrm{mM}$ Tris/ $\mathrm{HCl}$ of $\mathrm{pH}$ 9.5, $100 \mathrm{mM} \mathrm{NaCl}$, and $5 \mathrm{mM} \mathrm{MgCl}_{2}$, containing BCIP/NBT tablets (Sigma Chemical Co.; one tablet in $10 \mathrm{ml}$ ). As negative controls, the primary antibody was replaced by preimmune serum. All sections were visualized under an phase-contrast Optiphot Epifluoresence Microscope (Olympus).

\section{Confocal microscopy}

Oviductal cells were fixed in cold $4 \%$ paraformaldehyde in PBS of $\mathrm{pH} 7.4-7.6$ for $2 \mathrm{~h}$ and transferred to $10 \% \mathrm{w} / \mathrm{v}$ sucrose in PBS for $60 \mathrm{~min}$ at $4{ }^{\circ} \mathrm{C}$ and $30 \% \mathrm{w} / \mathrm{v}$ sucrose in PBS at $4{ }^{\circ} \mathrm{C}$ 


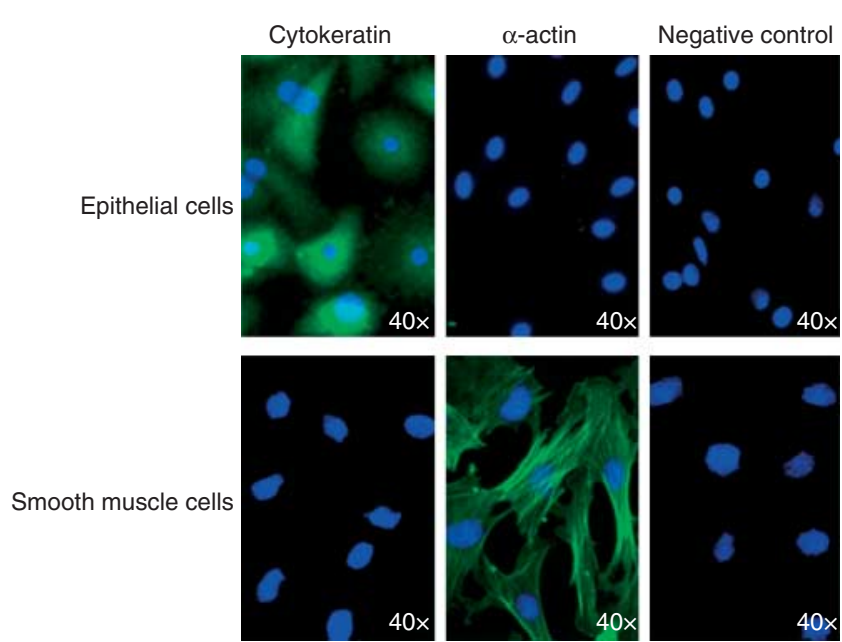

Figure 1 Expression of cytokeratin and $\alpha$-actin in the primary cultures of epithelial and smooth muscle cells from rat oviducts. Representative photomicrographs of primary cultures of epithelial and smooth muscle cells from rat oviducts were processed by immunofluorescence microscopy to detect the expression of cytokeratin and $\alpha$-actin. Note that cytokeratin (green) and $\boldsymbol{\alpha}$-actin (green) were only expressed in epithelial and smooth muscle cells respectively. Nuclei were stained with Hoechst 33342 (blue). Negative controls of the immunoreactivity were incubated with preimmune serum.

overnight. Then, they were blocked with 1\% PBS-BSA for $120 \mathrm{~min}$ and incubated with rabbit anti-ESR1 (Santa Cruz Biotechnology, Inc.) or mouse anti-G $\alpha_{i}$ (Santa Cruz Biotechnology, Inc.) antibody 1:50 in 1\% PBS-BSA in a humidified chamber overnight. Followed by three rinses in PBS, the cells were incubated for $60 \mathrm{~min}$ at room temperature with secondary antibody Alexa Fluor 555-conjugated goat anti-rabbit IgG (Invitrogen) or Alexa Fluor 588-conjugated goat anti-mouse IgG (Invitrogen) diluted in 1\% PBS-BSA. The samples were subsequently washed with PBS and mounted in DABCO (Sigma). As negative controls, the primary antibody was replaced by preimmune serum. All sections were visualized with laser scanning confocal microscopy on a Axiovert $100 \mathrm{M}$ microscope (Carl Zeiss, Jena, Germany).

\section{Statistical analysis}

Data for cAMP and IP3 assays or real-time PCR from cultured oviductal cells were replicated five times for each treatment (for each culture experiment, oviductal cells were recovered from a pool of six different rats). Results subjected to statistical analysis were expressed as mean \pm s.E.M. Data were subjected to Kruskal-Wallis test, followed by Mann-Whitney $U$ test for pairwise comparisons when overall significance was detected. Significance was accepted at $P<0.05$.

\section{Results}

\section{$E_{2}$ differentially regulates $C A M P$ and IP3 levels in secretory and smooth muscle cells of the rat oviduct}

This experiment was designed to determine the effect of $E_{2}$ on the level of cAMP and IP3 in the oviductal secretory and smooth muscle cells. First, we confirmed the purity of the cells by immunofluorescence staining of cytokeratin or $\alpha$-actin (Fig. 1) and also established that the primary cultures of the epithelial cells were conformed by secretory cells (Fig. 2). Therefore, secretory or smooth muscle cells were treated with ethanol or $\mathrm{E}_{2}$ during $0,1,3$, or $6 \mathrm{~h}$ and processed to measure the concentration of cAMP or IP3 as described in the 'Materials and methods' section. Replicas of this experiment are indicated in Figs 3 and 4.

Figure 3 shows that in the secretory cells, the basal cAMP level ranged from $48.1 \pm 21.1$ to $63.0 \pm 19.5 \mathrm{fmol} /$ $\mu \mathrm{g}$ of protein and in the smooth muscle cells it ranged from $25.8 \pm 5.9$ to $32.4 \pm 6.9 \mathrm{fmol} / \mu \mathrm{g}$ of protein. In the secretory cells, treatment with $E_{2}$ increased threefold the amount of CAMP at 3 and $6 \mathrm{~h}$ but not at $1 \mathrm{~h}$. In the smooth muscle cells, $E_{2}$ decreased threefold the amount of cAMP level at $3 \mathrm{~h}$ with no effect at 1 and $6 \mathrm{~h}$. On the other hand, Fig. 4 shows that $E_{2}$ did not affect the basal level of IP3 in the secretory cells (vehicle, $134 \pm 45-164 \pm 53 \mathrm{fmol} / \mu \mathrm{g}$ of protein and $E_{2}, 93 \pm 55-$ $117 \pm 044 \mathrm{fmol} / \mu \mathrm{g}$ of protein) while in the smooth muscle cells $E_{2}$ increased IP3 level to fourfold at $6 \mathrm{~h}$ (vehicle, $150 \pm 60 \mathrm{fmol} / \mu \mathrm{g}$ of protein and $E_{2}, 800 \pm$ $130 \mathrm{fmol} / \mu \mathrm{g}$ of protein) without any effect at $1 \mathrm{~h}$ (vehicle, $190 \pm 70 \mathrm{fmol} / \mu \mathrm{g}$ of protein and $E_{2}, 140 \pm 90 \mathrm{fmol} / \mu \mathrm{g}$ of protein) and $3 \mathrm{~h}$ (vehicle, $130 \pm 70 \mathrm{fmol} / \mu \mathrm{g}$ of protein and $E_{2}, 104 \pm 90 \mathrm{fmol} / \mu \mathrm{g}$ of protein).
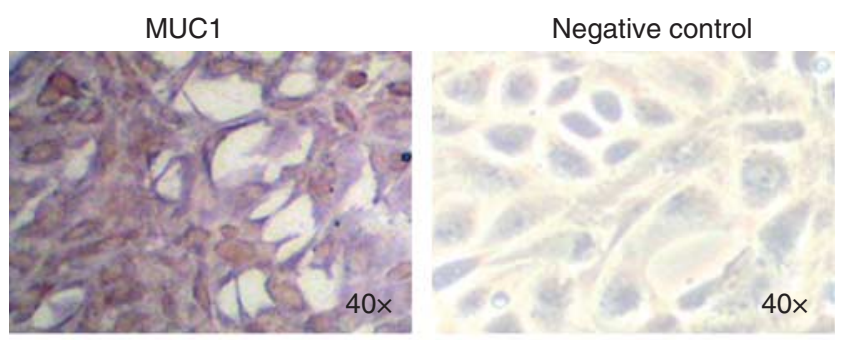

$\beta$-tubulin IV

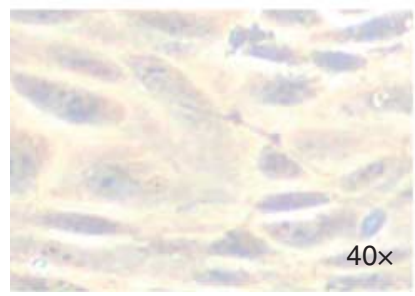

Negative control

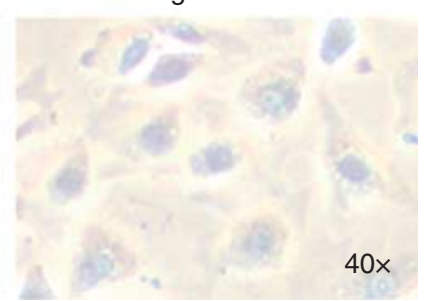

Figure 2 Primary cultures of epithelial cells from rat oviducts express MUC1 but not $\beta$-tubulin IV. Representative photomicrographs of primary cultures of epithelial cells from rat oviducts were processed by immunohistochemistry to detect the expression of MUC1 (marker for secretory cells) and $\beta$-tubulin IV (marker of ciliated cells). Note that positive immunoreactivity for MUC1 (purple) was only observed in the epithelial cells. Negative controls of the immunoreactivity were incubated with preimmune serum. 

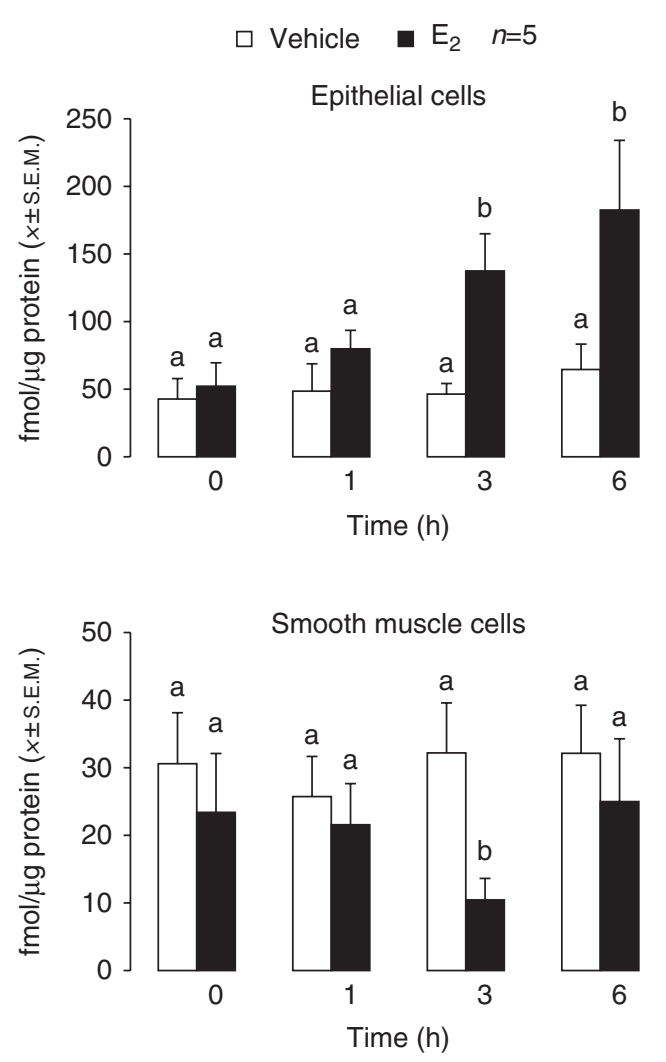

Figure 3 Effect of $E_{2}$ on the cAMP level in primary cultures of secretory and smooth muscle cells from rat oviducts. Primary cultures of secretory and smooth muscle cells from rat oviducts were treated with $E_{2} 10^{-9} \mathrm{M}$ and $0,1,3$, or $6 \mathrm{~h}$ later the cAMP level was determined by an enzyme immunoassay system. Note that in the epithelial cells, $E_{2}$ increased the cAMP level 3 and $6 \mathrm{~h}$ after treatment, while in the smooth muscle cells $\mathrm{E}_{2}$ decreased the cAMP level $6 \mathrm{~h}$ after treatment. This experiment consisted of five replicates. $a \neq b, P<0.05$.

\section{$E_{2}$ increased cAMP level by a nongenomic action in the oviductal secretory cells}

This experiment was designed to determine whether the effect of $E_{2}$ on the cAMP level in the secretory cells occurs under conditions in which RNA and protein synthesis is suppressed. For this we used ActD, which is an inhibitor of RNA and protein synthesis. Primary cultures of secretory cells from rat oviducts were divided into the following treatment groups: i) ethanol + DMSO, ii) $E_{2}+D M S O$, iii) ethanol + ActD, and iv) $E_{2}+$ ActD. At $3 \mathrm{~h}$ after treatment, cultured cells were processed to measure the concentration of cAMP as described in the 'Materials and methods' section. Replicas of this experiment are indicated in Fig. 5.

In the control group, the CAMP level was $58.3 \pm$ $10.1 \mathrm{fmol} / \mu \mathrm{g}$ of protein, while in the $E_{2}$-treated group it was $283.9 \pm 16.7 \mathrm{fmol} / \mu \mathrm{g}$ of protein. Administration of ActD alone or concomitant with $E_{2}$ neither affected the basal cAMP level $(49.6 \pm 12.3 \mathrm{fmol} / \mu \mathrm{g}$ of protein) nor the $E_{2}$-induced cAMP increase $(230.3 \pm 22.9 \mathrm{fmol} / \mu \mathrm{g}$ of protein) in the oviductal secretory cells.

\section{$E_{2}$ increased $C A M P$ level through activation of $E R$, $G \alpha_{i}$, and $A C$ in the oviductal secretory cells}

These experiments were carried out to determine whether the effect of $E_{2}$ on the cAMP level in the oviductal secretory cells is mediated by activation of ER, $\mathrm{G} \alpha_{i}$, and AC. For this, we used ICI 182780 that is an ER antagonist, PTX that is a highly specific inhibitor of heteromeric $G$ proteins of the $G_{i}$ class and SQ 22536 that is a selective inhibitor of AC activity. In each experiment, primary cultures of secretory cells from rat oviducts were divided into the following treatment groups: i) ethanol + DMSO, ii) $\mathrm{E}_{2}+\mathrm{DMSO}$, iii) ethanol + inhibitor, and iv) $\mathrm{E}_{2}+$ inhibitor. At $3 \mathrm{~h}$ after treatment, the cultured cells were processed to measure the concentration of cAMP as described in the 'Materials and methods' section. Replicas of this experiment are indicated in Fig. 6.

The results are shown in Fig. 6. In the control group, the cAMP level ranged from $51.1 \pm 10.3$ to $55.6 \pm$ $17.1 \mathrm{pmol} / \mu \mathrm{g}$ of protein while in the $\mathrm{E}_{2}$-treated group it ranged from $283.3 \pm 19.7$ to $316.9 \pm 51.3 \mathrm{fmol} / \mu \mathrm{g}$ of protein. Administration of ICl 182780 , PTX, or SQ 22536 alone did not affect the basal cAMP level (range, $46.8 \pm 19.2-64.2 \pm 14.1 \mathrm{fmol} / \mu \mathrm{g}$ of protein) although
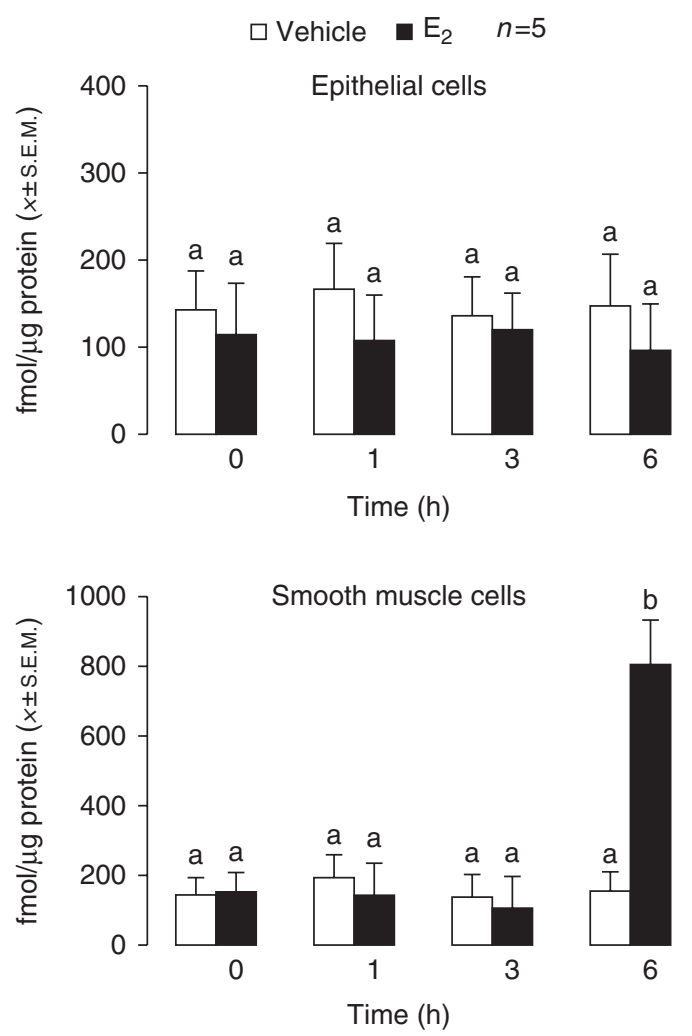

Figure 4 Effect of $E_{2}$ on the IP3 level in primary cultures of secretory and smooth muscle cells from rat oviducts. Primary cultures of secretory and smooth muscle cells from rat oviducts were treated with $\mathrm{E}_{2} 10^{-9} \mathrm{M}$ and 0,1 , 3, or $6 \mathrm{~h}$ later the IP3 level was determined by a radioreceptor assay. Note that in the epithelial cells, $E_{2}$ did not affect the IP3 level while in the smooth muscle cells $E_{2}$ increased the IP3 level $6 \mathrm{~h}$ after treatment. This experiment consisted of five replicates. $\mathrm{a} \neq \mathrm{b}, P<0.05$. 


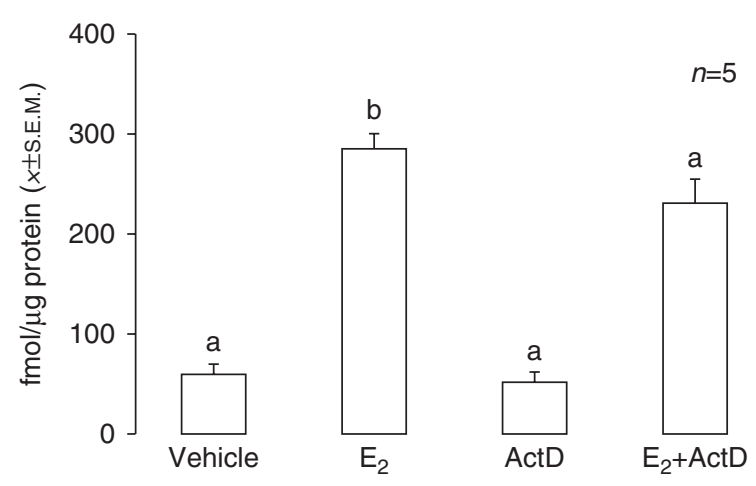

Figure 5 Effect of actinomycin D (ActD) on the $E_{2}$-induced cAMP increase in the oviductal secretory cells. Primary cultures of secretory cells from rat oviducts were treated with $E_{2} 10^{-9} \mathrm{M}$ alone or with the protein synthesis inhibitor ActD $1 \mu \mathrm{g} / \mu \mathrm{l}$ and $3 \mathrm{~h}$ later the cAMP level was determined by an enzyme immunoassay system. Note that ActD did not block the effect of $E_{2}$ on the cAMP level. This experiment consisted of five replicates. $a \neq b, P<0.05$.

blocked the $\mathrm{E}_{2}$-simulated cAMP increase (range, 83.4 \pm $21.5-57.5 \pm 9.9 \mathrm{fmol} / \mu \mathrm{g}$ of protein).

\section{$E_{2}$ increased cAMP level through activation of COMT in the oviductal secretory cells}

In this study, we investigated whether the effect of $E_{2}$ on the level of cAMP in the secretory cells occurs under condition in which COMT activity is suppressed. For this we used OR 486 which is a selective inhibitor of the COMT activity. Primary cultures of secretory cells from rat oviducts were divided into the following treatment groups: i) ethanol + DMSO; ii) $\mathrm{E}_{2}+\mathrm{DMSO}$; iii) ethanol + OR, 486; and iv) $\mathrm{E}_{2}+\mathrm{OR} 486$. At $3 \mathrm{~h}$ after treatment, the cultured cells were processed to measure the concentration of CAMP as described in the 'Materials and methods' section. Replicas of this experiment are indicated in Fig. 7A.

Figure 7A shows that in the control group, the cAMP level was $68.3 \pm 14.1 \mathrm{pmol} / \mu \mathrm{g}$ of protein, while in the $E_{2}$-treated group treated it was $243.9 \pm 36.7 \mathrm{fmol} / \mu \mathrm{g}$ of protein. Administration of OR 486 alone did not affect the basal cAMP level $(71.8 \pm 23.4)$ although blocked the $\mathrm{E}_{2}$-stimulated cAMP increase $(69.5 \pm 19.4)$.

\section{$E_{2}$ did not change the expression of the Comt, Cyp1a1, and Cyp1b1 transcripts in the oviductal secretory cells}

As COMT and the cytochrome P450 isoforms CYP1A1 and CYP1B1 convert $E_{2}$ into methoxyestradiols, we determined the effect of $\mathrm{E}_{2}$ on the mRNA levels for Comt, Cyp1a1, and Cyp1b1. Primary cultures of oviductal secretory cells were treated with ethanol or $E_{2} 10^{-9} \mathrm{M}$ and $3 \mathrm{~h}$ later the mRNA level for these enzymes was assessed by real-time PCR. Replicas of this experiment are indicated in Fig. 7B. $E_{2}$ treatment did not change the mRNA level of Comt, Cyp1a1, and Cyp1b1 in the oviductal secretory cells (Fig. 7B).

\section{$E_{2}$ induced colocalization between ESR1 and $G \alpha_{i}$ in the oviductal secretory cells}

In this study, we examined whether $E_{2}$ is able to induce colocalization between ESR1 and $\mathrm{G} \alpha_{\mathrm{i}}$ in the oviductal secretory cells. Primary cultures from rat oviductal secretory cells were treated with ethanol or $\mathrm{E}_{2} \mathrm{M}$ and $3 \mathrm{~h}$ later the expression and colocalization of ESR1 and $\mathrm{G} \alpha_{i}$ were assessed by confocal microscopy. This experiment was replicated five times.
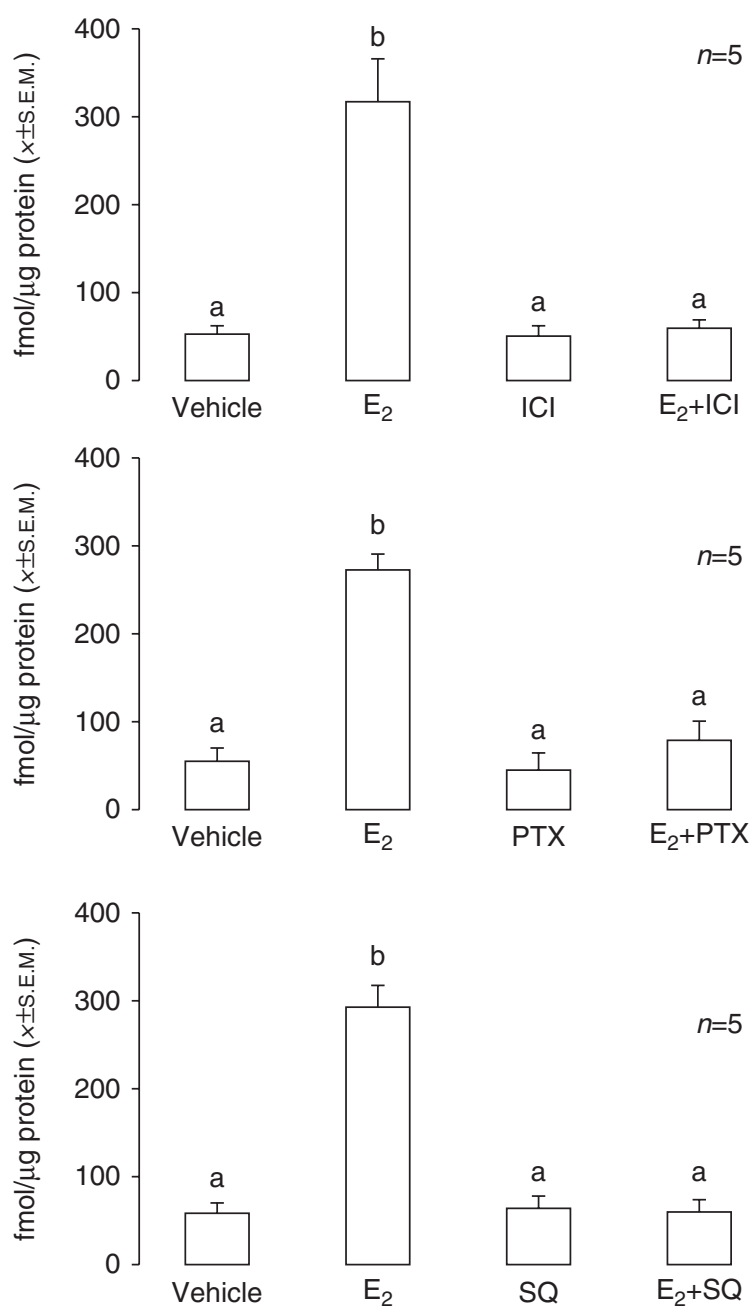

$n=5$

Figure 6 Effect of ICl 182 780, PTX, or SQ 22536 on the $E_{2}$-induced CAMP increase in the oviductal secretory cells. Primary cultures of secretory cells from rat oviducts were treated with $E_{2} 10^{-9} \mathrm{M}$ alone or with the estrogen receptor antagonist ICI $18278025 \mu \mathrm{g} / \mu \mathrm{l}$, the $\mathrm{G} \alpha_{i}$ protein inhibitor PTX $25 \mu \mathrm{g} / \mu \mathrm{l}$, or the adenylyl cyclase inhibitor SQ $225367.5 \mu \mathrm{g} / \mu \mathrm{l}$ and $3 \mathrm{~h}$ later the cAMP level was determined by an enzyme immunoassay system. Note that all three inhibitors blocked the effect of $E_{2}$ on the level of cAMP. This experiment consisted of five replicates. $\mathrm{a} \neq \mathrm{b}, P<0.05$. 

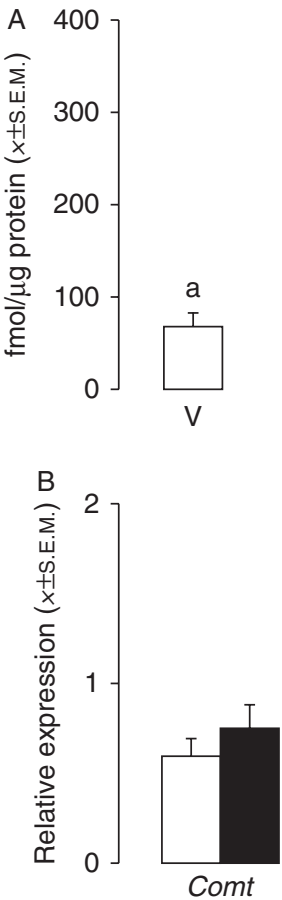

$n=5$
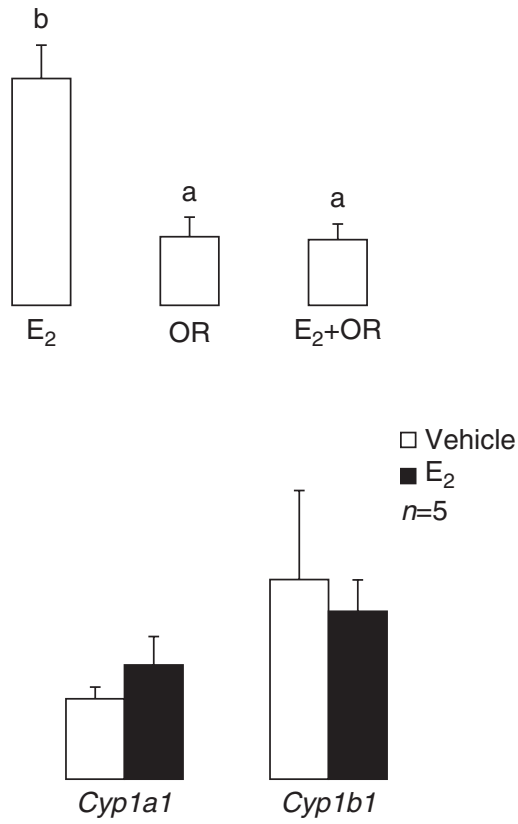

Figure 7 Effect of OR 486 on the $E_{2}$-induced cAMP increase and expression of Comt, Cyp1a1, and Cyp1b1 transcripts in the oviductal secretory cells. (A) Primary cultures of secretory cells from rat oviducts were treated with $\mathrm{E}_{2} 10^{-9} \mathrm{M}$ alone or with the cathecol-Omethyltransferase activity inhibitor OR $48625 \mu \mathrm{g} / \mu \mathrm{l}$ and $3 \mathrm{~h}$ later the cAMP level was determined by an enzyme immunoassay system. Note that OR 486 blocked the effect of $E_{2}$ on the cAMP level. This experiment consisted of five replicates. $a \neq b, P<0.05$. (B) Primary cultures of secretory cells from rat oviducts were treated with $E_{2} 10^{-9} \mathrm{M}$ and $3 \mathrm{~h}$ later the relative expression of the mRNA for Comt, Cyp1a1, and Cyp 1 b1 was determined by real-time PCR. The values were normalized to Gapdh. Note that $\mathrm{E}_{2}$ did not change the level of the transcripts.

In the control group, ESR1 distribution was found in the nuclear and extranuclear sites as previously reported for the rat oviductal epithelial cells (Orihuela et al. 2009), but colocalization was not observed between ESR1 and $\mathrm{G} \alpha_{i}$ proteins. However, $\mathrm{E}_{2}$ administration induced colocalization between ESR1 and $\mathrm{G} \alpha_{i}$ in the regions outside the nucleus of the oviductal secretory cells (Fig. 8).

\section{Discussion}

The $E_{2}$ nongenomic pathway that accelerates egg transport involves sequential activation of the signaling cascades of CAMP-PKA-PLC-IP3 in the rat oviduct (reviewed in Orihuela et al. (2013)). However, the role of the different cell phenotypes of the rat oviduct on this $E_{2}$ nongenomic pathway is still unknown. Herein, we show for the first time the separate contributions of the secretory and smooth muscle cells on the dynamic process that modulates CAMP and IP3 levels in response to an $E_{2}$ pulse. In the secretory cells, $E_{2}$ increased cAMP production between 3 and $6 \mathrm{~h}$, although the response of IP3 was not affected. In the smooth muscle cells, $E_{2}$ transiently decreased cAMP level at $3 \mathrm{~h}$ while IP3 level was increased at $6 \mathrm{~h}$. Thus, $\mathrm{E}_{2}$ differentially regulates cAMP and IP3 production in the secretory and smooth muscle cells of the rat oviduct. These differences may be attributed to the differential expression of the ER subtypes that exist in the secretory and smooth muscle cells of the rat oviduct (Mowa \& Iwanaga 2000, Orihuela et al. 2009) or to changes in the different pools of ER that initiate $E_{2}$ nongenomic actions between these two cellular phenotypes (Orihuela et al. 2009).

Further investigation to disclose the signaling pathway by which $E_{2}$ increases the level of cAMP in the secretory cells of the rat oviduct revealed that this effect of $E_{2}$ was by a nongenomic mechanism because suppression of mRNA protein synthesis by ActD did not prevent the effect of $E_{2}$ on the cAMP level. Blockade of ER by ICI 182780 and inhibition of AC by SQ 22536 suppressed the $E_{2}$-induced cAMP increase in the secretory cells of the rat oviduct indicating that the $E_{2}$ nongenomic pathway that increases CAMP requires binding of the hormone to its classical receptor and activation of AC. Several works have implicated to the $E_{2}$ nongenomic actions with the intracellular cAMP-signaling cascade. $\mathrm{E}_{2}$ activates $\mathrm{AC}$ in vascular smooth muscle, breast cancer, and uterine cells by a nongenomic mechanism (Aronica et al. 1994, Farhat et al. 1996), while acute stimulation of $\mathrm{Ca}^{2+}$ uptake induced by $\mathrm{E}_{2}$ is accompanied by increased cAMP content in rat duodenal cells and preosteoclastic cells (Fiorelli et al. 1996, Picotto et al. 1996). Our findings provide the first evidence of a nongenomic action of $E_{2}$ associated to a cAMP increase in the secretory cells of the mammalian oviduct. Probably, this $\mathrm{E}_{2}$ nongenomic action could be associated to the regulation of the secretory activity necessary to
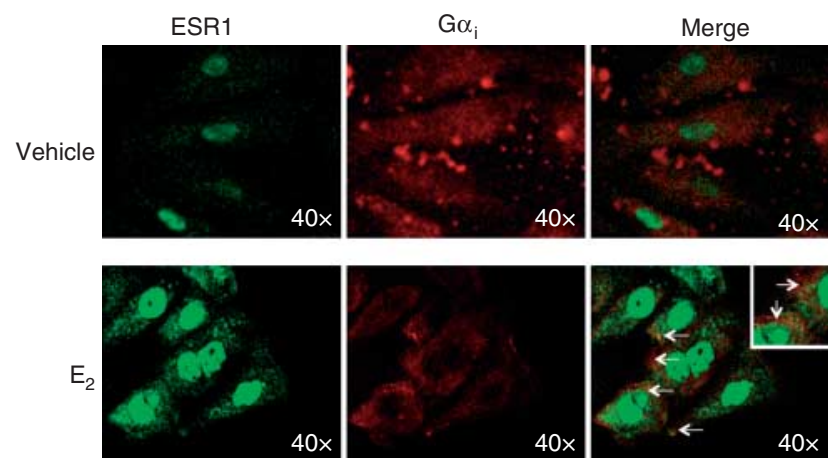

Figure 8 Estradiol induces colocalization between ESR1 and $\mathrm{G} \alpha_{\mathrm{i}}$ in the oviductal secretory cells. Representative photomicrographs obtained from primary cultures of oviductal secretory cells treated with $E_{2}$ $10^{-9} \mathrm{M}$ or vehicle and $3 \mathrm{~h}$ later the colocalization between ESR1 (green) and $\mathrm{G} \alpha_{\mathrm{i}}$ (red) were determined by confocal microscopy. The merged image display colocalization of ESR 1 and $\mathrm{G} \alpha_{i}$ as an orange signal (arrows) only in the group treated with $E_{2}$. Magnification is shown in the inset. 
accelerate egg transport in the rat oviduct. Alternatively, regulation of the tubal fluid formation by an increase in the level of CAMP may be useful in providing an adequate environment for some reproductive events as sperm migration, oocyte fertilization, or preimplantation embryo development. According with this assumption, previous works have reported that estrogens regulate the formation of tubal fluid secreted by the oviductal epithelial cells (Leese et al. 2001) and that cAMP increases fluid secretion into the oviductal lumen of several species (Leung et al. 1995, Chen et al. 2010, Liao et al. 2013).

There is increasing evidence that some biological effects of $E_{2}$ are in part mediated by its metabolites 2- and 4-methoxyestradiol (Mueck \& Seeger 2010, ParadaBustamante et al. 2013, Perez-Sepulveda et al. 2013), indicating an important role of methoxyestrogens in the signaling cascades of $E_{2}$ on its target organs. Our results showing that suppression of the COMT activity blocked the $E_{2}$-stimulated cAMP accumulation in the secretory cells of the rat oviduct suggest that this nongenomic action of $E_{2}$ requires previous conversion of $E_{2}$ to methoxyestrogens. Furthermore, the enzymes necessary to metabolize estrogens are present in the oviductal secretory cells, although their expression was not regulated by $E_{2}$. In order to corroborate the importance of methoxyestrogens in the nongenomic action of $E_{2}$ that increases CAMP in the oviductal secretory cells, it is necessary to treat these cells with methoxyestrogens and evaluate their effects on the level of cAMP; however, this was not explored in this work.

The role of $G$ proteins in the nongenomic actions of $E_{2}$ has been documented in a variety of cell types (Levin 1999, Fu \& Simoncini 2008). In this context, we have found that the ADP-ribosylating agent PTX blocked the effect of $E_{2}$ on the cAMP production in the secretory cells, indicating a requirement for heterotrimeric $\mathrm{G}_{\mathrm{i} / \mathrm{o}^{-}}$ type proteins in this nongenomic action of $E_{2}$. This is supported by the fact that $\mathrm{E}_{2}$ also induced colocalization between ESR1 and $\mathrm{G} \alpha_{i}$ in non-nuclear sites of these cells, suggesting coupling of ESR1 with $\mathrm{G} \alpha_{i}$ protein as a requisite for the $E_{2}$-induced $C A M P$ increase. Although all major subclass of $G$ proteins are expressed in many cell types, it appears that $\mathrm{G} \alpha_{\mathrm{i}}$ subclass is in a great mode, the one most often linked with the $E_{2}$ nongenomic actions involving the participation of a presumptive ESR1 localized in extranuclear sites (Wyckoff et al. 2001, Kumar et al. 2007, Lin et al. 2011, Watson et al. 2012). To our knowledge, this is the first report showing association between ESR 1 and $\mathrm{G} \alpha_{\mathrm{i}}$ in extranuclear sites of the epithelium cells that may mediate an $E_{2}$ nongenomic action in the mammalian oviduct. On the other hand, we cannot assure whether this ESR1-C $\alpha_{i}$ colocalization occurs in the plasma membrane or is a consequence of diminution of the ESR1 or $\mathrm{G} \alpha_{\mathrm{i}}$ expression in the secretory cells, because subcellular fractionation or immunoprecipitation experiments were not done in this work. Further studies are necessary to disclose the molecular and cellular mechanisms that explain how the activation of the $\mathrm{G} \alpha_{i}$ protein participates in the $E_{2}$ nongenomic pathway of the rat oviduct.

$E_{2}$ regulates the expression of insulin-like growth factor 1 (IGF1), IGF1-binding proteins, and IGF1 receptors in neurons of the CNS and in reproductive tissues (Wimalasena et al. 1993, Sahlin et al. 1994, Azcoitia et al. 1999). Furthermore, IGF1 stimulates the accumulation of cAMP in mouse astrocytes and in the preoptic area and hypothalamus of the rat. Moreover, IGF1 is able to induce activation of ER via an increase in intracellular CAMP level in the rat uterine cells (Aronica \& Katzenellenbogen 1993, Bartella et al. 2012). Probably, the $E_{2}$-induced cAMP increase observed in the secretory cells of the rat oviduct involves functional cross talk between $E_{2} / E R$ and IGF1 signaling pathways, but this remains undetermined.

In summary, we have found that $E_{2}$ differentially regulates CAMP and IP3 production in the secretory and smooth muscle cells of the rat oviduct. In the secretory cells, $E_{2}$ increases CAMP production by a nongenomic action that requires COMT and ER activation, coupling between ESR1 and $\mathrm{G} \alpha_{i}$, and stimulation of AC. These findings provide new evidence for understanding the contribution of the different cellular phenotypes present in the rat oviduct on the nongenomic regulation of the egg transport exerted by $\mathrm{E}_{2}$.

\section{Declaration of interest}

The authors declare that there is no conflict of interest that could be perceived as prejudicing the impartiality of the research reported.

\section{Funding}

This work received financial support from grants FONDECYT no. 1110662 and Proyecto BASAL FBO-07.

\section{References}

Acconcia F, Ascenzi P, Bocedi A, Spisni E, Tomasi V, Trentalance A, Visca P \& Marino M 2005 Palmitoylation-dependent estrogen receptor $\boldsymbol{\alpha}$ membrane localization: regulation by $17 \beta$-estradiol. Molecular Biology of the Cell 16 231-237. (doi:10.1091/mbc.E04-07-0547)

Aronica SM \& Katzenellenbogen BS 1993 Stimulation of estrogen receptormediated transcription and alteration in the phosphorylation state of the rat uterine estrogen receptor by estrogen, cyclic adenosine monophosphate, and insulin-like growth factor-I. Molecular Endocrinology 7 743-752.

Aronica SM, Krauss WL \& Katzenellenbogen BS 1994 Estrogen action via the cAMP signaling pathway: stimulation of adenylate cyclase and cAMP-regulated gene transcription. PNAS 91 8517-8521. (doi:10.1073/ pnas.91.18.8517)

Azcoitia I, Sierra A \& Garcia-Segura LM 1999 Neuroprotective effects of estradiol in the adult rat hippocampus: interaction with insulinlike growth factor-I signalling. Journal of Neuroscience Research $\mathbf{5 8}$ 815-822. (doi:10.1002/(SICI)1097-4547(19991215)58:6<815::AID-JNR8 $>3.0 .(\mathrm{CO} ; 2-\mathrm{R})$ 
Bartella V, De Marco P, Malaguarnera R, Belfiore A \& Maggiolini M 2012 New advances on the functional cross-talk between insulin-like growth factor-I and estrogen signaling in cancer. Cellular Signalling 24 1515-1521. (doi:10.1016/j.cellsig.2012.03.012)

Chen MH, Chen H, Zhou Z, Ruan YC, Wong HY, Lu YC, Guo JH, Chung YW, Huang PB, Huang HF et al. 2010 Involvement of CFTR in oviductal $\mathrm{HCO} 3-$ secretion and its effect on soluble adenylate cyclasedependent early embryo development. Human Reproduction 25 1744-1754. (doi:10.1093/humrep/deq094)

Croxatto HB 1996 Gamete transport. In Reproductive Endocrinology, Surgery and Technology, 3rd edn, pp 385-402. Eds EY Adashi, JA Rock\& Z Rosenwaks. Philadelphia: Lippincott-Raven Publishers.

Croxatto HB 2002 Physiology of gamete and embryo transport through the fallopian tube. Reproductive BioMedicine Online 4 160-169. (doi:10.1016/S1472-6483(10)61935-9)

DeSouza MM, Mani SK, Julian J \& Carson D 1998 Reduction of mucin-1 expression during the receptive phase in the rat uterus. Biology of Reproduction 58 1503-1507. (doi:10.1095/biolreprod58.6.1503)

Farhat MY, Abiyounes S, Dingaan B, Vargas R \& Ramwell PW 1996 Estradiol increases cyclic adenosine monophosphate in rat pulmonary vascular smooth muscle cells by a nongenomic mechanism. Journal of Pharmacology and Experimental Therapeutics 276 652-657.

Fiorelli G, Gori F, Frediani U, Franceschelli F, Tanini A, Tosti-Guerra C, Benvenuti S, Gennari L, Bechereni L \& Brandi ML 1996 Membrane binding sites and non-genomic effects of estrogen in cultured human preosteoclastic cells. Journal of Steroid Biochemistry and Molecular Biology 59 233-240. (doi:10.1016/S0960-0760(96)00092-1)

Fu XD \& Simoncini T 2008 Extra-nuclear signaling of estrogen receptors. IUBMB Life 60 502-510. (doi:10.1002/iub.80)

Hill BJ, Gebre S, Schlicker B, Jordan R \& Necessary S 2010 Nongenomic inhibition of coronary constriction by $17 \beta$-estradiol, 2-hydroxyestradiol, and 2-methoxyestradiol. Canadian Journal of Physiology and Pharmacology 88 147-152. (doi:10.1139/Y09-120)

Kumar P, Wu Q, Chambliss KL, Yuhanna IS, Mumby SM, Mineo C, Tall GG \& Shaul PW 2007 Direct interactions with $\mathrm{G} \alpha \mathrm{i}$ and $\mathrm{G} \beta \gamma$ mediate nongenomic signaling by estrogen receptor- $\alpha$. Molecular Endocrinology 21 1370-1380. (doi:10.1210/me.2006-0360)

Leese HJ, Tay JI, Reischl J \& Downing SJ 2001 Formation of fallopian tubal fluid: role of a neglected epithelium. Reproduction 121 339-346. (doi:10.1530/rep.0.1210339)

Leung AY, Wong PY, Gabriel SE, Yankaskas JR \& Boucher RC 1995 cAMPbut not $\mathrm{Ca}(2+)$-regulated $\mathrm{Cl}-$ conductance in the oviduct is defective in mouse model of cystic fibrosis. American Journal of Physiology $\mathbf{2 7 9}$ C708-C712.

Levin ER 1999 Cellular functions of the plasma membrane estrogen receptor. Trends in Endocrinology and Metabolism 10 374-377. (doi:10. 1016/S1043-2760(99)00192-7)

Liao SB, Cheung KH, Cheung MP, To YT, O WS \& Tang F 2013 Adrenomedullin increased the short-circuit current in the pig oviduct through chloride channels via the CGRP receptor: mediation by CAMP and calcium ions but not by nitric oxide. Biology of Reproduction $\mathbf{8 9}$ 1-6. (doi:10.1095/biolreprod.113.109934)

Lin AH, Leung GP, Leung SW, Vanhoutte PM \& Man RY 2011 Genistein enhances relaxation of the spontaneously hypertensive rat aorta by transactivation of epidermal growth factor receptor following binding to membrane estrogen receptors- $\alpha$ and activation of a G protein-coupled, endothelial nitric oxide synthase-dependent pathway. Pharmacological Research 63 181-189. (doi:10.1016/j.phrs.2010.11.007)

Livak KJ \& Schmittgen TD 2001 Analysis of relative gene expression data using real-time quantitative PCR and the $2(\mathrm{~T})$ ( - Delta Delta C) method. Methods 25 402-408. (doi:10.1006/meth.2001.1262)

Lösel R \& Wehling M 2003 Nongenomic actions of steroid hormones. Nature Reviews. Molecular Cell Biology 4 46-56. (doi:10.1038/nrm1009)

Lösel RM, Falkenstein E, Feuring M, Schultz A, Tillmann HC, RossolHaseroth K \& Wehling M 2003 Nongenomic steroid action: controversies, questions, and answers. Physiological Reviews 83 965-1006.

Moore GD \& Croxatto HB 1988a Synthetic microspheres transferred to the rat oviduct on day 1 of pregnancy mimic the transport of native ova. Journal of Reproduction and Fertility 82 735-742. (doi:10.1530/jrf.0.0820735)

Moore GD \& Croxatto HB $1988 b$ Effects of delayed transfer and treatment with oestrogen on the transport of microspheres by the rat oviduct. Journal of Reproduction and Fertility 83 795-802. (doi:10.1530/jrf.0.0830795)
Morales B, Barrera N, Uribe P, Mora C \& Villalón M 2000 Functional cross talk after activation of $\mathrm{P} 2$ and $\mathrm{P} 1$ receptors in oviductal ciliated cells. American Journal of Physiology 279 C658-C669.

Morales P, Reyes P, Vargas M, Rios M, Imarai M, Cardenas H, Croxatto H, Orihuela P, Vargas R, Fuhrer J et al. 2006 Infection of human fallopian tube epithelial cells with Neisseria gonorrhoeae protects cells from tumor necrosis factor $\alpha$-induced apoptosis. Infection and Immunity $\mathbf{7 4}$ 3643-3650. (doi:10.1128/IAI.00012-06)

Mowa CN \& Iwanaga T 2000 Differential distribution of oestrogen receptor$\alpha$ and $-\beta$ mRNAs in the female reproductive organ of rats as revealed by in situ hybridization. Journal of Endocrinology 165 59-66. (doi:10.1677/ joe.0.1650059)

Mueck AO \& Seeger H 2010 2-Methoxyestradiol - biology and mechanism of action. Steroids 75 625-631. (doi:10.1016/j.steroids.2010.02.016)

Nadal A, Díaz M \& Valverde MA 2001 The estrogen trinity: membrane, cytosolic, and nuclear effects. News in Physiological Sciences $\mathbf{1 6}$ 251-255.

Nilsson S, Mäkelä S, Treuter E, Tujague M, Thomsen J, Andersson G, Enmark E, Petterson K, Warner M \& Gustafsson JA 2001 Mechanisms of estrogen action. Physiological Reviews 81 1535-1565.

Nutu M, Weijdegård B, Thomas $P$, Thurin-Kjellberg A, Billig $H$ \& Larsson DG 2009 Distribution and hormonal regulation of membrane progesterone receptors $\beta$ and $\gamma$ in ciliated epithelial cells of mouse and human fallopian tubes. Reproduction Biology and Endocrinology 789. (doi:10.1186/1477-7827-7-89)

Orihuela PA, Ríos M \& Croxatto HB 2001 Disparate effects of estradiol on egg transport and oviductal protein synthesis in mated and unmated rats. Biology of Reproduction 65 1232-1237. (doi:10.1095/biolreprod65. 4.1232)

Orihuela PA, Parada-Bustamante A, Cortés PP, Gatica C \& Croxatto HB 2003 Estrogen receptor, cyclic adenosine monophosphate, and protein kinase $\mathrm{A}$ are involved in the nongenomic pathway by which estradiol accelerates oviductal oocyte transport in cyclic rats. Biology of Reproduction 68 1225-1231. (doi:10.1095/biolreprod.102.011395)

Orihuela PA, Parada-Bustamante A, Zúñiga LM \& Croxatto HB 2006 Inositol triphosphate participates in an oestradiol nongenomic signalling pathway involved in accelerated oviductal transport in cycling rats. Journal of Endocrinology 188 579-588. (doi:10.1677/joe.1.06448)

Orihuela PA, Zuñiga LM, Rios M, Parada-Bustamante A, Sierralta WD, Velásquez LA \& Croxatto HB 2009 Mating changes the subcellular distribution and the functionality of estrogen receptors in the rat oviduct. Reproduction Biology and Endocrinology 7 139. (doi:10.1186/14777827-7-139)

Orihuela PA, Parada-Bustamante A, Cardenas H, Tapia-Pizarro A, Oróstica L \& Reuquén P 2013 Mating effects on female reproductive organs: the paradigm of estrogen signaling pathways in the oviduct. In Human and Animal Mating, 1st edn, pp 1-30. Eds M Nakamara \& T Ito. New York: Nova Science Publishers.

Ortíz ME, Villalón M \& Croxatto HB 1979 Ovum transport and fertility following postovulatory treatment with estradiol in rats. Biology of Reproduction 21 1163-1167. (doi:10.1095/biolreprod21.5.1163)

Parada-Bustamante A, Orihuela PA, Ríos M, Navarrete-Gómez PA, Cuevas CA, Velásquez LA, Villalón MJ \& Croxatto HB 2007 Catechol$O$-methyltransferase and methoxyestradiols participate in the intraoviductal nongenomic pathway through which estradiol accelerates egg transport in cycling rats. Biology of Reproduction 77 934-941. (doi:10.1095/biolreprod.107.061622)

Parada-Bustamante A, Orihuela PA, Ríos M, Cuevas CA, Oróstica ML, Velásquez LA, Villalón MJ \& Croxatto HB 2010 A non-genomic signaling pathway shut down by mating changes the estradiol-induced gene expression profile in the rat oviduct. Reproduction 139 631-644. (doi:10.1530/REP-09-0218)

Parada-Bustamante A, Croxatto HB, Cárdenas H \& Orihuela PA 2012 Differential participation of endothelin receptors in estradiol-induced oviductal egg transport acceleration in unmated and mated rats. Asian Pacific Journal of Reproduction 1 17-21. (doi:10.1016/S2305-0500(13) 60042-1)

Parada-Bustamante A, Orihuela PA, Molina C, Cardenas H, Reuquén P, Valencia C \& Rincón R 2013 Hydroxyestradiols and methoxyestradiols as endogenous factors associated to physiological and physiopathological conditions. In Estradiol: Synthesis, Health and Drug Interactions, 1st edn, pp 1-30. Eds R Pameri\& S Grimaudo. New York: Nova Science Publishers. 
Perez-Sepulveda A, España-Perrot PP, Norwitz ER \& Illanes SE 2013 Metabolic pathways involved in 2-methoxyestradiol synthesis and their role in preeclampsia. Reproductive Sciences 20 1020-1029. (doi:10.1177/1933719113477483)

Picotto G, Massheimer V \& Boland R 1996 Acute stimulation of intestinal cell calcium influx induced by $17 \beta$-estradiol via cAMP messenger system. Molecular and Cellular Endocrinology 119 129-134. (doi:10. 1016/0303-7207(96)03799-9)

Rincón-Rodríguez RJ, Oróstica $M L$, Díaz $P$, Reuquén P, Cárdenas H \& Orihuela PA 2013 Changes in the gene expression pattern induced by 2-methoxyestradiol in the mouse uterus. Endocrine 44 773-783. (doi:10.1007/s12020-013-9921-2)

Ríos M, Hermoso M, Sánchez TM, Croxatto HB \& Villalón MJ 2007 Effect of oestradiol and progesterone on the instant and directional velocity of microsphere movements in the rat oviduct: gap junctions mediate the kinetic effect of oestradiol. Reproduction, Fertility, and Development 19 634-640. (doi:10.1071/RD06146)

Sahlin L, Norstedt G \& Eriksson H 1994 Estrogen regulation of the estrogen receptor and insulinlike growth factor-I in the rat uterus: a potential coupling between effects of estrogen and IGF-I. Steroids 59 421-430. (doi:10.1016/0039-128X(94)90011-6)

Shao R, Weijdegård B, Fernandez-Rodriguez J, Egecioglu E, Zhu C, Andersson N, Thurin-Kjellberg A, Bergh C \& Billig H 2007 Ciliated epithelial-specific and regional-specific expression and regulation of the estrogen receptor- $\beta 2$ in the fallopian tubes of immature rats: a possible mechanism for estrogen-mediated transport process in vivo. American Journal of Physiology 293 E147-E158.

Turner CD 1991 Endocrinology of the ovary. In General Endocrinology, 3rd edn, pp 365-409. Ed CD Turner. Philadelphia: WB Saunders Company.

Watson CS, Jeng YJ, Hu G, Wozniak A, Bulayeva N \& Guptarak J 2012 Estrogen- and xenoestrogen-induced ERK signaling in pituitary tumor cells involves estrogen receptor- $\alpha$ interactions with $G$ protein- $\alpha$ i and caveolin I. Steroids 77 424-432. (doi:10.1016/j.steroids.2011.12.025)

Wimalasena J, Meehan D, Dostal R, Foster JS, Cameron M \& Smith M 1993 Growth factors interact with estradiol and gonadotropins in the regulation of ovarian cancer cell growth and growth factor receptors. Oncology Research 5 325-337.

Wyckoff MH, Chambliss KL, Mineo C, Yuhanna IS, Mendelsohn ME, Mumby SM \& Shaul PW 2001 Plasma membrane estrogen receptors are coupled to endothelial nitric-oxide synthase through $\mathrm{G} \alpha(\mathrm{i})$. Journal of Biological Chemistry 276 27071-27076. (doi:10.1074/jbc.M100312200)

Received 4 March 2014

First decision 9 April 2014

Revised manuscript received 14 May 2014

Accepted 11 June 2014 